\title{
KESETARAAN HANYU SHUIPING KAOSHI LEVEL I-IV DENGAN CEFR PADA KETERAMPILAN BERBICARA BAHASA MANDARIN
}

\author{
Ayu Trihardini, Aprilia Ruby Wikarti, Riyadh Abdurrahman, Resma Anggrini \\ Mandarin Education Department, Faculty of Languages and Arts, Universitas Negeri Jakarta \\ Campus A, DE Building 204, Jl. Rawamangun Muka Jakarta Timur \\ ayu.trihardini@unj.ac.id, apriliarubyw.s@unj.ac.id
}

\begin{abstract}
Abstrak
Sejalan dengan derasnya perkembangan era disrupsi teknologi revolusi industri 4.0, pembelajaran bahasa asing dituntut untuk mempunyai standar tingkat penguasaan sebagai acuan pengukuran kemahiran. Standar yang digunakan di Eropa dan diadaptasi di seluruh dunia yaitu Common European Framework of Reference for Languages (CEFR). Standar CEFR level B2 merupakan standar minimal lulusan program studi kebahasaan pada Fakultas Bahasa dan Seni Universitas Negeri Jakarta (FBS UNJ). Sementara dalam konteks penguasaan bahasa Mandarin, secara khusus digunakan acuan Hanyu Shuiping Kaoshi (HSK). Tulisan ini akan membahas mengenai kesetaraan HSK I-IV dengan CEFR pada keterampilan berbicara bahasa Mandarin.

Berdasarkan hasil penelitian, kesetaraan antara HSK dengan CEFR pada keterampilan berbicara dapat disimpulkan sebagai berikut: (1) Materi ajar keterampilan berbicara HSK level I setara dengan CEFR $O$ hingga level A1, HSK level II setara dengan CEFR level A2, HSK level III setara dengan CEFR level A2 hingga B1, sedangkan HSK level IV setara dengan CEFR level B1; (2) Materi soal HSKK level dasar setara dengan CEFR $O$ hingga level A2, HSKK level menengah setara dengan CEFR level A2 hingga B1.

Hasil penelitian ini dapat menjadi dasar bagi Asosiasi Program Studi Mandarin Indonesia (APSMI) dalam mengusulkan kesetaraan HSK dengan CEFR versi pengajar bahasa Mandarin di Indonesia, seperti yang telah diajukan Hanban dan Asosiasi Guru Bahasa Mandarin di Prancis dan Jerman. Hasil penelitian mengenai kesetaraan HSK dengan CEFR ini juga mempertegas perwujudan mutu dan jati diri bangsa dalam kaitan Kerangka Kualifikasi Nasional Indonesia (KKNI) yang sedang dikembangkan secara nasional. Peneliti menyarankan APSMI agar mengambil peran dalam mengembangkan sebuah standar pendidikan bahasa Mandarin di Indonesia, terutama standar kompetensi pendidikan dan pelatihan bahasa Mandarin secara nasional di bidang-bidang tertentu yang memerlukan keterampilan berbicara bahasa Mandarin.
\end{abstract}

Kata Kunci: Hanyu Shuiping Kaoshi, CEFR, Keterampilan Berbicara, Bahasa Mandarin

\begin{abstract}
The rapid flow development of the era of technological disruption in the industrial revolution 4.0, foreign language learning required to have a standard level of mastery as a reference to measure proficiency. The standard used in Europe and adapted throughout the world is the Common European Framework of Reference for Languages (CEFR). CEFR level B2 standard is a minimum standard for graduates of language study programs at the Faculty of Language and Arts, State University of Jakarta (FBS UNJ). While in the context of mastering Mandarin, specifically the Hanyu Shuiping Kaoshi (HSK) reference is used. This paper will discuss HSK equality with CEFR in Mandarin speaking skills.

Based on the results of the study, the equality between HSK and CEFR on speaking skills can be concluded as follows: (1) Teaching materials on speaking skills for HSK level I is equivalent to CEFR $O$ to level A1; HSK level II is equivalent to CEFR level A2; HSK level III is equivalent to CEFR level A2 to B1; while HSK level IV is equivalent to CEFR level B1; (2) Proficiency Test Material for HSKK beginner level is equivalent to CEFR 0 to level A2; HSKK for intermediate level is equivalent to CEFR level A2 to B1. The results of this study can be the basis for the Association of Indonesian Mandarin Study Programs
\end{abstract}


(APSMI) in proposing Indonesian version of HSK correspondend to the level of CEFR, as already asserted by Hanban, also by French and German Associations of Chinese Language Teachers. The results of this research also reinforce the realization of quality and national identity in relation to the Indonesian National Qualification Framework (KKNI), which is being developed nationally. The researcher suggests that APSMI take a role in developing a standard of Mandarin language education in Indonesia, especially the national competency standard of Mandarin education and training in certain fields that require Mandarin speaking skills.

Keywords: Hanyu Shuiping Kaoshi, CEFR, Speaking Skills, Mandarin

\section{A. PENDAHULUAN}

Derasnya perkembangan era disrupsi teknologi revolusi industri 4.0 menjadikan komunikasi dalam berbagai konteks kehidupan sosial kian intens hingga melewati batas regional antarnegara. Komunikasi antarbangsa dengan menggunakan bahasa asing tertentu merupakan hal lazim yang tidak dapat dihindari. Sejalan dengan hal tersebut, pembelajaran bahasa asing dituntut untuk mempunyai standar tingkat penguasaan sebagai acuan pengukuran kemahiran. Di Eropa, terdapat kerangka acuan umum Eropa sebagai standar pembelajaran bahasa asing yang dikenal dengan Common European Framework of Reference for Languages (CEFR). CEFR mencakupi standar penyusunan silabus, pedoman kurikulum, ujian, buku teks dan lain-lain, umum digunakan di Eropa dan diadaptasi di banyak belahan dunia.

Sesuai dengan roadmap Fakultas Bahasa dan Seni Universitas Negeri Jakarta yaitu menghasilkan lulusan yang siap dalam menghadapi Masyarakat Ekonomi ASEAN (MEA), FBS UNJ menggunakan CEFR sebagai standar acuan dalam pembelajaran bahasa asing, dengan standar minimal lulusan CEFR level B2. Program Studi Pendidikan Bahasa Mandarin (PSPBM) sebagai bagian dari FBS UNJ mendukung tercapainya standar tersebut demi upaya pengembangan kualitas pengajaran bahasa Mandarin di Indonesia. Saat ini, dokumen kurikulum PSPBM (mencakupi deskripsi mata kuliah, capaian pembelajaran mata kuliah) telah menggunakan standar CEFR. Namun dalam proses pembelajaran keterampilan berbahasa Mandarin, kompetensi penguasaan bahasa Mandarin masih menyesuaikan diri dengan standar Hanyu Shuiping Kaoshi (HSK). HSK adalah ujian kompetensi bahasa Mandarin terstandar yang ditentukan oleh pemerintah Republik Rakyat Tiongkok (RRT) bagi penutur asing. Ujian HSK terbagi menjadi 6 level, dengan level 1 sebagai level pemula.

Permasalahan yang kemudian muncul yaitu, adanya perbedaan pendapat mengenai kesetaraan HSK dengan CEFR. Sekurang-kurangnya terdapat 3 versi yang ditemukan oleh peneliti. Pertama, versi pemerintah RRT. Pemerintah RRT menyatakan bahwa kesetaraan HSK dengan CEFR adalah sebagai berikut:

Tabel 1. Kesetaraan Level HSK dengan CEFR Menurut Pemerintah RRT (Sumber: Website Hanban)

\begin{tabular}{|c|c|c|}
\hline HSK & CEFR & $\begin{array}{c}\text { Penguasaan Kosakata } \\
\text { Lebih dari 5000 }\end{array}$ \\
\hline Level 1 & A1 & 2500 \\
\hline Level 2 & A2 & 1200 \\
\hline Level 3 & B1 & 600 \\
\hline Level 4 & B2 & 300 \\
\hline Level 5 & C1 & 150 \\
\hline Level 6 & C2 & \\
\hline
\end{tabular}


Kedua dan ketiga, versi Asosiasi Guru Bahasa Mandarin di Prancis dan Jerman. Asosiasi guru tersebut menyatakan bahwa kesetaraan HSK dengan CEFR dapat dilihat:

Tabel 2. Kesetaraan Level HSK dengan CEFR Menurut Asosiasi Guru Bahasa Mandarin di Prancis dan Jerman (Sumber: Wikipedia)

\begin{tabular}{|c|c|c|}
\hline HSK & $\begin{array}{c}\text { CEFR } \\
\text { (Menurut Asosiasi Guru Bahasa } \\
\text { Mandarin Prancis) }\end{array}$ & $\begin{array}{c}\text { CEFR } \\
\text { (Menurut Asosiasi Guru Bahasa } \\
\text { Mandarin Jerman) }\end{array}$ \\
\hline Level 1 & di bawah A1 & - \\
\hline Level 2 & A1.1 & A1.1 (tanpa menulis) \\
\hline Level 3 & A1-A2 & A1 \\
\hline Level 4 & A2 & A2 \\
\hline Level 5 & B1-B2 & B2 \\
\hline Level 6 & B2-C1 & ( \\
\hline
\end{tabular}

Ketiga versi di atas merupakan kesetaraan HSK dengan CEFR secara umum, tanpa mempertimbangkan jenis keterampilan berbahasa. Tulisan ini akan membahas mengenai kesetaraan HSK level I-IV dengan CEFR pada keterampilan berbicara bahasa Mandarin. Kesetaraan dinilai menggunakan analisis isi berupa analisis terhadap materi ajar dan materi soal latihan pada buku 'Panduan Persiapan HSK' di setiap level. Oleh sebab terdapat ujian tersendiri pada keterampilan berbicara yaitu HSKK, maka diperlukan pula pembahasan kesetaraan HSKK dengan CEFR yang dinilai berdasarkan analisis materi soal HSKK.

Dengan adanya penelitian mengenai kesetaraan HSK dengan CEFR, diharapkan mutu dan jati diri bangsa dapat dapat dipertegas dalam kaitan Kerangka Kualifikasi Nasional Indonesia (KKNI) yang sedang dikembangkan secara nasional. Hasil penelitian juga dapat menjadi masukan bagi Asosiasi Program Studi Mandarin Indonesia (APSMI) dalam menentukan sikap mengenai kesetaraan HSK dengan CEFR yaitu mengambil peran dalam mengembangkan sebuah standar pendidikan bahasa Mandarin di Indonesia, terutama standar kompetensi pendidikan dan pelatihan bahasa Mandarin secara nasional di bidang-bidang tertentu yang memerlukan keterampilan berbicara bahasa Mandarin.

\section{(1) Keterampilan Berbicara dalam Kurikulum PSPBM}

Seluruh keterampilan berbahasa saling mempengaruhi satu sama lain, keterampilan berbicara dapat diperoleh karena menguasai keterampilan menyimak, begitupun keterampilan menulis dapat diperoleh karena menguasai keterampilan membaca. Dalam konteks pengajaran bahasa asing, seluruh keterampilan berbahasa hanya dapat dikuasai melalui praktik dan latihan. Fungsi bahasa sebagai alat komunikasi, nampak terutama pada keterampilan berbicara. Tarigan (2013) mengungkapkan, berbicara adalah kemampuan mengucapkan bunyi-bunyi artikulasi atau kata-kata untuk mengekspresikan, menyatakan atau menyampaikan pikiran, gagasan atau perasaan. Dengan demikan, berbicara bukan hanya pembunyian ujaran oleh alat ucap, sehingga pembelajaran keterampilan berbicara tidak terbatas pada imitasi bunyi, intonasi, namun juga pengetahuan kosakata, penggunaan kata-kata, perangkaian pola-pola kalimat, dan pengekspresian gagasan. Bahasa Mandarin merupakan bahasa tonal, namun pengajaran keterampilan berbicara bahasa Mandarin juga harus mencakupi hal-hal tersebut di atas.

Menurut Zhang (2008: 18) pengajaran keterampilan berbicara bahasa Mandarin memiliki beberapa kelebihan yaitu: (1) pengajaran menekankan pada kebutuhan komunikasi, pemelajar menguasai ragam lisan melalui proses komunikasi; (2) praktik percakapan berupa 
gabungan latihan per unit dan latihan konteks penggunaan, untuk melatih kemampuan berkomunikasi pemelajar secara lebih menyeluruh; (3) pengajaran mementingkan latihan penggunaan materi pembelajaran di kelas percakapan untuk meningkatkan minat dan motivasi pemelajar. Zhang berpendapat pengajaran keterampilan berbicara bahasa Mandarin masih belum mempunyai teori pengajaran yang komprehensif dan sistematis, teori belum sesuai dengan perkembangan pengajaran dan kebutuhan praktis keterampilan berbicara yang meningkat pesat.

Pengajaran keterampilan berbicara bahasa Mandarin tidak terlepas dari keterampilan menyimak. Pada kurikulum program studi, kedua keterampilan ini diajarkan dalam rangkaian mata kuliah Menyimak dan Berbicara. Dengan mempertimbangkan standar kelulusan CEFR level B2, maka mata kuliah keterampilan berbahasa Mandarin pada kurikulum PSPBM FBS UNJ diberikan dalam 7 semester dengan pembagian sebagai berikut:

Tabel 3. Penguasaan CEFR dalam Mata Kuliah Keterampilan Berbahasa PSPBM

\begin{tabular}{|c|c|c|}
\hline Semester ke- & Nama Mata Kuliah & $\begin{array}{c}\text { Perkiraan } \\
\text { Kesetaraan CEFR }\end{array}$ \\
\hline 1 & $\begin{array}{l}\text { - Menyimak dan Berbicara Dasar I } \\
\text { - } \quad \text { Membaca dan Menulis Dasar I } \\
\text { - Tata Bahasa I }\end{array}$ & A1 \\
\hline 2 & $\begin{array}{ll}\text { - } & \text { Menyimak dan Berbicara Dasar II } \\
\text { - } & \text { Membaca dan Menulis Dasar II } \\
\text { - } & \text { Tata Bahasa II }\end{array}$ & $\mathrm{A} 2$ \\
\hline 3 & $\begin{array}{ll}\text { - } & \text { Menyimak dan Berbicara Dasar III } \\
\text { - } & \text { Membaca dan Menulis Dasar III } \\
\text { - } & \text { Tata Bahasa III } \\
\end{array}$ & B1 \\
\hline 4 & $\begin{array}{ll}\text { - } & \text { Menyimak dan Berbicara Dasar IV } \\
\text { - } & \text { Membaca dan Menulis Dasar IV } \\
\text { - } & \text { Tata Bahasa IV } \\
\end{array}$ & B1 \\
\hline 5 & $\begin{array}{l}\text { - Menyimak dan Berbicara Lanjut I } \\
\text { - } \quad \text { Membaca dan Menulis Lanjut I }\end{array}$ & B2 \\
\hline 6 & $\begin{array}{l}\text { - Menyimak dan Berbicara Lanjut II } \\
\text { - } \quad \text { Membaca dan Menulis Lanjut II }\end{array}$ & B2 \\
\hline
\end{tabular}

Mata kuliah keterampilan berbicara pada PSPBM UNJ diampu secara tim oleh penutur jati dan dosen lokal. Pengajaran keterampilan berbicara bahasa Mandarin pada PSPBM merupakan pengajaran bahasa berdurasi panjang bagi peserta didik dewasa berbahasa ibu bahasa Indonesia yang belajar di lingkungan bahasanya sendiri. Keterampilan berbicara mencakupi pengetahuan mengenai fonologi bahasa Mandarin, kemampuan memilih dan merangkai kata, hingga pada akhirnya mengungkapkan pikiran dalam pelbagai konteks dan kondisi sehingga mampu menguasai kebutuhan komunikasi. Tahapan-tahapan ini harus secara rinci dijabarkan dalam capaian pembelajaran pada kurikulum dan diimplementasikan melalui materi, latihan serta praktik yang mendukung pada proses pembelajaran.

\section{(2) HSK dan HSKK}

Berdasarkan tujuan penyelenggaran tes, Heaton (1988:172-173) mengklasifikasikan tes menjadi 4 jenis: (1) tes pencapaian belajar (achievement test), bertujuan untuk mengukur capaian belajar yang diperoleh pemelajar suatu program bahasa pada saat tes dijalankan; (2) 
tes kemahiran (proficiency test), bertujuan untuk menguji seberapa baik seorang pemelajar dalam menggunakan suatu bahasa; (3) tes bakat (aptitude test), bertujuan untuk mengukur kemampuan potensial pemelajar pada bidang tertentu, sehingga dapat memprediksi kemampuan seseorang di kemudian hari; dan (4) tes diagnostik (diagnostic test), bertujuan untuk mendiagnosa masalah-masalah yang muncul dalam pembelajaran. Kemudian Brown (2004) menambahkan jenis yang ke lima yaitu tes penempatan (placement test), bertujuan untuk menempatkan pemelajar pada tingkat tertentu untuk mengikuti suatu program bahasa.

Dilihat dari kategorisasi tersebut, HSK tergolong dalam tes kemahiran yaitu tes untuk menguji seberapa baik kompetensi seseorang menggunakan bahasa Mandarin. HSK adalah tes kompetensi pertama dan juga satu-satunya di RRT untuk mengukur level kemampuan bahasa Mandarin seorang peserta didik asing. Materi yang diujikan pada tes HSK terkait dalam 2 kelompok besar: (1) mencakupi 4 keterampilan berbahasa yaitu keterampilan menyimak, berbicara, membaca dan menulis, (2) mencakupi pengetahuan kebahasaan yaitu tata bunyi, kosa kata, tata bahasa, aksara Han dan lain sebagainya (Zhang, 2006: 252).

HSKK merupakan tes HSK yang dikhususkan untuk keterampilan berbicara. Berdasarkan situs Hanban, diketahui beberapa informasi mengenai HSKK. Berbeda dengan HSK yang dbagi menjadi 5 tingkatan, HSKK dibagi menjadi 3 tingkatan. Adapun hubungan antara HSK dan HSKK ditunjukkan pada tabel di bawah ini:

Tabel 4. Hubungan Antara HSK dan HSKK (Sumber: Website Hanban)

\begin{tabular}{|c|c|c|}
\hline HSK Level I & \multirow{2}{*}{ HSKK Level Dasar } & \multirow{2}{*}{ Menguasai 0-200 kosakata } \\
\hline HSK Level II & & \\
\hline HSK Level III & \multirow{2}{*}{ HSKK Level Menengah } & \multirow{2}{*}{ Menguasai 200-900 kosakata } \\
\hline HSK Level IV & & \\
\hline HSK Level V & HSKK Level Lanjut & Menguasai 900-3000 kosakata \\
\hline
\end{tabular}

Peserta yang melampaui HSKK level dasar dapat mengerti dan menggunakan bahasa Mandarin dalam topik pembicaraan sehari-hari untuk memenuhi keperluan komunikasi yang mendasar. Peserta yang melampaui HSKK level menengah dapat mengerti dan cukup fasih menggunakan bahasa Mandarin untuk berkomunikasi secara lisan dengan penutur jati bahasa Mandarin. Peserta yang melampaui HSKK level lanjutan dapat mengerti dan fasih menggunakan bahasa Mandarin untuk mengungkapkan pendapat sendiri secara lisan.

HSKK yang dibahas pada penelitian ini yaitu HSKK level dasar dan HSKK level menengah, sehingga terkait pula dengan HSK level I-IV. Dengan demikian, penelitian kesetaraan HSKK dengan CEFR ini terbatas pada penguasaan 0 hingga 900 kosakata.

\section{B. HASIL DAN PEMBAHASAN}

\section{(1) Kesetaraan Materi Ajar HSK dengan CEFR}

Seperti yang dijelaskan di muka, HSK dan HSKK merupakan 2 tes yang berbeda. HSKK secara khusus digunakan sebagai tes keterampilan berbicara bahasa Mandarin. Pada penelitian ini, kesetaraan materi ajar HSK dilihat dari buku "Panduan Persiapan HSK". Pada bagian pendahuluan buku 'Panduan Persiapan HSK level I-IV' dipaparkan bahwa buku menyediakan latihan komunikatif independen dalam setiap bab untuk kebutuhan tes lisan HSK (HSKK). Latihan yang dimaksud mencakupi aktivitas berpasangan dan aktivitas kelompok. Peneliti melakukan analisis terhadap materi ajar yang terdapat pada buku "Panduan Persiapan HSK level I-IV" serta terhadap materi ajar keterampilan berbicara 
sebagai interaksi dan produksi CEFR level A1 hingga B1. Adapun materi ajar keterampilan berbicara sebagai aktivitas interaksi dan produksi yang terdapat pada dokumen CEFR, beracuan pada kompetensi sebagai berikut:

Tabel 6. Kompetensi Keterampilan Berbicara pada CEFR Level A1, A2, B1 (Sumber: diterjemahkan dari Common European Frame Work of Reference for Language)

\begin{tabular}{|c|c|}
\hline Tingkatan CEFR & Kompetensi \\
\hline Level A1 & $\begin{array}{l}\text { 1. Memperkenalkan diri sendiri } \\
\text { 2. Bertanya tentang informasi diri seperti tempat tinggal, orang yang } \\
\text { dikenal, apa yang dimiliki } \\
\text { 3. Merespon pernyataan sederhana tentang kebutuhan singkat atau } \\
\text { topik familiar }\end{array}$ \\
\hline Level A2 & $\begin{array}{l}\text { 1. Menyapa orang lain dengan bentuk sopan sehari-hari yang sederhana } \\
\text { 2. Bertanya pada orang lain tentang bagaimana bereaksi terhadap berita } \\
\text { 3. Menghadapi pertukaran sosial yang sangat pendek } \\
\text { 4. Tanya jawab tentang apa yang dilakukan saat bekerja dan saat waktu } \\
\text { luang } \\
\text { 5. Mengundang dan merespon undangan } \\
\text { 6. Mendiskusikan apa yang harus dilakukan, pergi ke mana dan } \\
\text { membuat janji, serta membuat dan menerima tawaran } \\
\text { 7. Melakukan aktivitas di negara berbahasa bersangkutan (melakukan } \\
\text { transaksi di took, kantor pos atau bank; mendapatkan informasi } \\
\text { sederhana tentang bepergian; menggunakan transportasi umum seperti } \\
\text { bis, kereta dan taksi, menanyakan dan memberitahu arah, membeli } \\
\text { tiket; meminta dan menyediakan barang, jasa sehari-hari) }\end{array}$ \\
\hline Level A2+ & $\begin{array}{l}\text { 1. Memulai, melanjutkan, dan menutup percakapan tatap muka } \\
\text { sederhana } \\
\text { 2. Cukup paham untuk mengatur interaksi sehari-hari yang sederhana } \\
\text { 3. Membuat diri sendiri memahami dan bertukar ide/informasi pada } \\
\text { topik umum dalam situasi sehari-hari yang dapat diperkirakan; } \\
\text { menyediakan bantuan bagi orang lain bila diperlukan } \\
\text { 4. Menghadapi situasi sehari-hari yang dapat diperkirakan meskipun } \\
\text { harus berkompromi dengan pesan dan mencari kata-kata } \\
\text { 5. Berinteraksi dengan mudah dalam situasi terstruktur, memberikan } \\
\text { bantuan namun masih berkemampuan terbatas dalam mengikuti diskusi } \\
\text { terbuka } \\
\text { 6. Melakukan monolog untuk menunjukkan perasaan dalam bentuk } \\
\text { sederhana, mendeskripsikan lingkungan sekitarnya seperti orang, } \\
\text { tempat, pengalaman kerja/belajar } \\
\text { 7. Mendeskripsikan aktivitas lampau dan pengalaman pribadi } \\
\text { 8. Mendeskripsikan rencana dan persiapan; menjelaskan apa yang } \\
\text { disukai/tidak disukai mengenai sesuatu } \\
\text { 9. Mendeskripsikan peristiwa dan aktivitas secara pendek dan mendasar } \\
\text { 10. Menggunakan bahasa deskripsi sederhana untuk membuat } \\
\text { pernyataan umum mengenai perbandingan, dan kepemilikan }\end{array}$ \\
\hline Le & $\begin{array}{l}\text { 1. Memahami diskusi di sekitarnya yang tersedia dalam dialek standar } \\
\text { 2. Memberikan atau mencari pandangan/pendapat pribadi dalam diskusi }\end{array}$ \\
\hline
\end{tabular}




\begin{tabular}{|l|l|}
\hline informal dengan teman \\
3. Menggambarkan ide utama ujaran agar mudah dipahami \\
4. Menggunakan bahasa sederhana secara lebih luas secara fleksibel \\
untuk menggambarkan keinginan \\
5. Melanjutkan dialog atau diskusi meskipun kadang sulit dipahami, dan \\
berhenti untuk merencanakan ujaran secara gramatikal dan leksikal \\
dengan perbaikan, terutama dalam produksi ujaran bebas \\
6. Menghadapi situasi percakapan tidak rutin yang terjadi di transportasi \\
umum \\
$\begin{array}{l}\text { 7. Menghadapi situasi yang mungkin muncul ketika membuat rencana } \\
\text { berpergian melalui agen atau ketika sedang berpergian } \\
\text { 8. Melakukan dialog mengenai topik umum tanpa persiapan } \\
\text { 9. Membuat keluhan } \\
\text { 10. Berinisiatif dalam wawancara/konsultasi (misalnya memunculkan } \\
\text { topik baru), namun sangat bergantung pada pewawancara dalam } \\
\text { berinteraksi } \\
\text { 11. Meminta seseorang untuk mengklarifikasi apa yang mereka baru } \\
\text { katakan }\end{array}$ \\
$\begin{array}{l}\text { 1. Mengambil pesan untuk mengkomunikasikan kebutuhan } \\
\text { 2. Menjelaskan masalah } \\
\text { 3. Menyediakan informasi nyata yang diperlukan dalam } \\
\text { wawancara/konsultasi (misalnya menjelaskan gejala penyakit kepada } \\
\text { dokter) namun dengan ketepatan yang tersebata } \\
\text { 4. Menjelaskan mengapa sesuatu merupakan sebuah masalah } \\
\text { 5. Merangkum dan memberikan pendapat mengenai cerita pendek, } \\
\text { artikel, ujaran, diskusi, wawancara atau dokumentari, serta memberikan } \\
\text { jawaban atas pertanyaan lanjutan yang detil } \\
\text { 6. Melaksanakan wawancara yang telah dipersiapkan sebelumnya, } \\
\text { mengecek dan mengkonfirmasi informasi, meskipun kadang harus } \\
\text { bertanya ulang jika respon orang yang diwawancara meluas } \\
\text { 7. Menjelaskan bagaimana cara melakukan sesuatu, memberikan } \\
\text { instruksi detil } \\
\text { 8. Melakukan pertukaran informasi faktual dalam hal-hal yang rutin dan } \\
\text { tidak rutin dalam bidangnya dengan percaya diri }\end{array}$ \\
\hline
\end{tabular}

Tabel 7. Kesetaraan Materi Ajar HSK Level I dengan CEFR

\begin{tabular}{|c|c|c|c|c|}
\hline \multirow[t]{2}{*}{ No } & \multirow[t]{2}{*}{ Materi Ajar HSK Keterampilan Berbicara Level I } & \multicolumn{3}{|c|}{$\begin{array}{l}\text { Kesetaraan } \\
\text { dengan CEFR }\end{array}$} \\
\hline & & $\mathbf{A 1}$ & A2 & B1 \\
\hline 1. & Ejaan Hanyu Pinyin & - & - & - \\
\hline 2. & Melafalkan bunyi bahasa Mandarin & - & - & - \\
\hline 3. & Merespon salam, ucapan terima kasih, maaf, panggilan, perkenalan & $\mathrm{V}$ & & \\
\hline 4. & $\begin{array}{l}\text { Menyapa dengan menggunakan hubungan keluarga atau } \\
\text { kekerabatan (ayah, ibu, anak laki-laki, anak perempuan) }\end{array}$ & $\mathrm{V}$ & & \\
\hline 5. & $\begin{array}{l}\text { Menjawab pertanyaan mengenai tempat tinggal atau berada di } \\
\text { tempat tertentu }\end{array}$ & $\mathrm{V}$ & & \\
\hline
\end{tabular}




\begin{tabular}{|c|c|c|}
\hline 6. & $\begin{array}{l}\text { Mendeskripsikan letak, kondisi benda sekitar (belakang, dalam, } \\
\text { depan) }\end{array}$ & $\mathrm{V}$ \\
\hline 7. & Angka 1-10, untuk mengekspresikan uang, waktu, usia & $\mathrm{V}$ \\
\hline 8. & $\begin{array}{l}\text { Kegiatan sehari-hari (makan, minum, nama makanan, nama } \\
\text { minuman, menelepon, menggunakan komputer, menonton tv, film, } \\
\text { membaca, membeli, mendengar, menulis, belajar, duduk, ujian) }\end{array}$ & $\mathrm{V}$ \\
\hline 9. & Mengekspresikan cara, waktu terjadi kegiatan & $\mathrm{V}$ \\
\hline 10. & $\begin{array}{l}\text { Menayakan informasi diri terkait profesi umum (guru, teman } \\
\text { sekelas, murid, dokter) }\end{array}$ & $\mathrm{V}$ \\
\hline 11. & $\begin{array}{l}\text { Menanyakan topik umum seperti cuaca (dingin, panas, hujan), } \\
\text { keadaan (cantik) }\end{array}$ & $\mathrm{V}$ \\
\hline 12. & Menyatakan kesanggupan/kemampuan (dapat, bisa) & $\mathrm{V}$ \\
\hline 13. & $\begin{array}{l}\text { Bertanya menggunakan berapa, siapa, apa, apakah, bagaimana } \\
\text { tentang kebutuhan singkat atau topik familiar }\end{array}$ & $\mathrm{V}$ \\
\hline 14. & Mengungkapkan keinginan sederhana & $\mathrm{V}$ \\
\hline
\end{tabular}

Materi ajar keterampilan berbicara HSK level I setara dengan CEFR level A1. Bahasa Mandarin merupakan bahasa yang mempunyai aksara sendiri dan bertonal, sehingga dalam materi HSK level I terdapat pengenalan ejaan Hanyu Pinyin dan pelafalan. Ejaan Hanyu Pinyin mentranskripsikan aksara Han ke dalam aksara Latin, sehingga dapat dibaca dan dipelajari lebih luas. Ejaan serta pelafalan bunyi bahasa bukan merupakan materi ajar dalam CEFR. Kedua materi yang terkait tata bunyi bahasa Mandarin ini tidak setara dengan level manapun di CEFR, namun merupakan materi yang memang harus ada. Materi lainnya yang sesuai dengan CEFR A1 yaitu melangsungkan percakapan sederhana dan merespon pernyataan sederhana terkait topik umum, serta mendeskripsikan tempat tinggal atau orang sekitar.

Materi berupa gambar muncul di setiap tingkatan, sejak materi ajar HSK level I hingga level IV.

Tabel 6. Kesetaraan Materi Ajar HSK Level II dengan CEFR

\begin{tabular}{|c|c|c|c|c|}
\hline \multirow[t]{2}{*}{ No } & \multirow[t]{2}{*}{ Materi Ajar HSK Keterampilan Berbicara Level II } & \multicolumn{3}{|c|}{$\begin{array}{l}\text { Kesetaraan } \\
\text { dengan CEFR }\end{array}$} \\
\hline & & A1 & A2 & B1 \\
\hline 1. & $\begin{array}{l}\text { Berinteraksi pada topik umum yang dapat diperkirakan (olahraga, } \\
\text { hobi, sakit, ulang tahun, berbelanja, beristirahat) }\end{array}$ & & $\sqrt{ }$ & \\
\hline 2. & Menolong/menyediakan bantuan bagi orang lain & & $\mathrm{V}$ & \\
\hline 3. & Membuat deskripsi sederhana mengenai perbandingan & & $\mathrm{V}$ & \\
\hline 4. & Menjelaskan apa yang disukai dan tidak disukai & & $\sqrt{ }$ & \\
\hline 5. & $\begin{array}{l}\text { Melakukan monolog untuk menunjukkan perasaan dalam bentuk } \\
\text { sederhana }\end{array}$ & & $\mathrm{V}$ & \\
\hline 6. & Mendeskripsikan aktivitas lampau dan pengalaman pribadi & & $\mathrm{V}$ & \\
\hline 7. & Mendeskripsikan rencana & & $\mathrm{V}$ & \\
\hline 8. & Melakukan transaksi di toko, restoran, kantor pos, bank & & $\sqrt{ }$ & \\
\hline 9. & Mengundang dan merespon undangan & & $\mathrm{V}$ & \\
\hline 10. & Menanyakan dan memberitahu arah & & $\mathrm{V}$ & \\
\hline
\end{tabular}




\begin{tabular}{|c|c|c|c|}
\hline 11. & Menggunakan transportasi umum & $\sqrt{ }$ & \\
\hline 12. & Memperkenalkan orang lain & $\sqrt{ }$ & \\
\hline 13. & Menyampaikan pendapat, alasan & & $\sqrt{ }$ \\
\hline 14. & $\begin{array}{l}\text { Mendeskripsikan keadaan lingkungan sekitar seperti orang, benda, } \\
\text { tempat, pengalaman belajar }\end{array}$ & $\mathrm{V}$ & \\
\hline 15. & Mendeskripsikan peristiwa secara umum & $\mathrm{V}$ & \\
\hline 16. & Menyuruh, meminta pertolongan orang lain & $\sqrt{ }$ & \\
\hline 17. & Menjelaskan masalah & & $\mathrm{V}$ \\
\hline 18. & Menggambarkan keinginan dengan bahasa yang sederhana & $\sqrt{ }$ & \\
\hline
\end{tabular}

Materi ajar keterampilan berbicara HSK level II secara umum setara dengan CEFR level A2. Siswa yang berada pada CEFR level A2, dapat melakukan aktivitas sehari-hari di negara berbahasa bersangkutan. Pada buku Panduan HSK level II, terdapat materi melakukan transaksi jual beli di toko, restoran, kantor pos, bank dan juga menggunakan transportasi umum seperti bis. Hanya terdapat 2 materi yang tidak setara yaitu menyampaikan pendapat disertai alasan, serta menjelaskan masalah. Kedua materi tersebut setara dengan CEFR level B1.

Tabel 8. Kesetaraan Materi Ajar HSK Level III dengan CEFR

\begin{tabular}{|c|c|c|c|c|}
\hline \multirow[t]{2}{*}{ No } & \multirow[t]{2}{*}{ Materi Ajar HSK Keterampilan Berbicara Level III } & \multicolumn{3}{|c|}{$\begin{array}{l}\text { Kesetaraan } \\
\text { dengan CEFR }\end{array}$} \\
\hline & & A1 & A2 & B1 \\
\hline 1. & $\begin{array}{l}\text { Menyapa orang lain yang bukan anggota inti keluarga dengan } \\
\text { bentuk sopan yang sederhana }\end{array}$ & & $\sqrt{ }$ & \\
\hline 2. & Melakukan dialog mengenai topik umum tanpa persiapan & & & $\mathrm{V}$ \\
\hline 3. & Menjelaskan hobi/kegemaran & & $\sqrt{ }$ & \\
\hline 4. & Memberi jawban atas pertanyaan lanjutan yang detil & & & $\mathrm{V}$ \\
\hline 5. & Mengecek infromasi & & & $\sqrt{ }$ \\
\hline 6. & Menghadapi situasi percakapan tidak rutin di tempat umum & & & $\sqrt{ }$ \\
\hline 7. & Membandingkan keadaan & & $\mathrm{V}$ & \\
\hline 8. & Mendiskusikan apa yang harus dilakukan & & $\sqrt{ }$ & \\
\hline 9. & Menyatakan pengecualian, tidak hanya, tentu saja & & $\sqrt{ }$ & \\
\hline 10. & Menyatakan pujian sederhana & & $\sqrt{ }$ & \\
\hline 11. & Mengeluhkan tentang kesehatan & & & $\sqrt{ }$ \\
\hline
\end{tabular}

Materi ajar keterampilan berbicara HSK level III setara dengan CEFR level A2 dan B1. Pada buku Panduan HSK level III, terdapat materi yang berkaitan dengan memberikan pendapat, alasan, serta penjelasan detil. Hal-hal tersebut berada dalam CEFR level B1.

Tabel 9. Kesetaraan Materi Ajar HSK Level IV dengan CEFR

\begin{tabular}{|l|l|l|l|l|}
\hline \multirow{2}{*}{ No } & \multicolumn{1}{|c|}{ Materi Ajar HSK Keterampilan Berbicara Level IV } & \multicolumn{3}{|c|}{$\begin{array}{c}\text { Kesetaraan } \\
\text { dengan CEFR }\end{array}$} \\
\cline { 3 - 5 } & \multicolumn{1}{|c|}{ A1 } & A2 & B1 \\
\hline 1. & $\begin{array}{l}\text { Menggambarkan keinginan: Hampir, selalu, kadang, ketika, baru } \\
\text { saja, masih, seperti, saling, akumulasi }\end{array}$ & & & $\mathrm{V}$ \\
\hline
\end{tabular}




\begin{tabular}{|c|c|c|c|}
\hline 2. & Mendeskripsikan perencanaan suatu kegiatan/proyek & & $\sqrt{ }$ \\
\hline 3. & $\begin{array}{l}\text { Menggunakan angka untuk menyatakan persentase, kali lipat, } \\
\text { bagian, diskon, kira-kira, km, harga, jarak }\end{array}$ & & $\sqrt{ }$ \\
\hline 4. & Memuji kehebatan orang lain & & $\sqrt{ }$ \\
\hline 5. & $\begin{array}{l}\text { Melakukan dialog ketika sedang berpergian (boarding pass, nomor } \\
\text { penerbangan, mendarat, visa) }\end{array}$ & & $\sqrt{ }$ \\
\hline 6. & $\begin{array}{l}\text { Nama benda (jiaozi, baozi, biscuit, fax, jendela, kata, cinta, } \\
\text { kesalahan, jawaban, pisau, formulir, alamat, bumi, tempat, perut, } \\
\text { SMS, anak, hukum, perasaan, lengan, jalan tol, gaji, iklan, } \\
\text { peraturan, jus, boks, api, skill, furnitur, pendidikan, opera Beijing, } \\
\text { ekonomi, uang kecil, pingpong, anggur, kulit, temperamen) }\end{array}$ & & $\sqrt{ }$ \\
\hline 7. & $\begin{array}{l}\text { Menyatakan perasaan maaf merepotkan/mengganggu dengan } \\
\text { alasan }\end{array}$ & & $\sqrt{ }$ \\
\hline 8. & Melakukan konsultasi ke dokter & & $\sqrt{ }$ \\
\hline 9. & Merangkum dan menyampaikan pendapat & & $\sqrt{ }$ \\
\hline 10. & $\begin{array}{l}\text { Menjelaskan masalah, kronologis (memberi contoh, selain itu, } \\
\text { perubahan, ulang lagi, jika tidak maka, oleh karena, hasilnya, lalu) }\end{array}$ & & $\sqrt{ }$ \\
\hline 11. & $\begin{array}{l}\text { Menyampaikan kondisi (bodoh, sukses, jujur, abai, bangga, hilang, } \\
\text { macet, rileks, kaya, rumit, berani, sengaja, malu, tebal, enerjik, } \\
\text { aktif, bersemangat, palsu, sombong, gugup, takut, kasihan, } \\
\text { menderita, sulit, pedas, malas, kalem, sejuk, berantakan, sabar, } \\
\text { ramai) }\end{array}$ & & $\sqrt{ }$ \\
\hline 12. & Mendaftar suatu kegiatan & $\sqrt{ }$ & \\
\hline 13. & $\begin{array}{l}\text { Menghadapi situasi sehari-hari yang dapat diperkirakan } \\
\text { (mengunjungi, mencicip, merokok, dinas luar, menabung, dandan, } \\
\text { memprint, menunggu, membayar, memfotokopi, mengatur, } \\
\text { lembur, bercanda, potong rambut) }\end{array}$ & $\sqrt{ }$ & \\
\hline 14. & $\begin{array}{l}\text { Menyatakan pertentangan, larangan, penolakan, keluhan, } \\
\text { penyesalan }\end{array}$ & & $\sqrt{ }$ \\
\hline 15. & Memahami diskusi di lingkungan sekitar & & $\sqrt{ }$ \\
\hline 16. & Mencari pendapat dalam diskusi informal dengan teman & & $\sqrt{ }$ \\
\hline 17. & Menjelaskan karakteristik suatu benda, kelebihan, kekurangan & & $\sqrt{ }$ \\
\hline 18. & Memberikan dukungan, rekomendasi & & $\sqrt{ }$ \\
\hline 19. & Mendeskripsikan pengalaman & & $\sqrt{ }$ \\
\hline 20. & Mendeskripsikan perbedaan & & $\sqrt{ }$ \\
\hline 21. & Menyatakan instruksi/urutan/prosedur, persyaratan & & $\sqrt{ }$ \\
\hline 22. & Menghadapi situasi tersesat & & $\sqrt{ }$ \\
\hline
\end{tabular}

Materi ajar keterampilan berbicara HSK level IV secara umum setara dengan CEFR level B1. Siswa yang berada pada CEFR level B1, dapat melakukan dialog mengenai topik umum tanpa persiapan. Hanya terdapat 2 materi yang tidak setara yaitu mendaftar suatu kegiatan dan menghadapi situasi sehari-hari yang dapat diperkirakan. Kedua materi tersebut setara dengan CEFR level A2. 


\section{(2) Kesetaraan Materi Soal HSKK dengan CEFR}

Pada penelitian ini, kesetaraan materi soal ujian dilihat dari contoh soal HSKK. Diantaranya yaitu contoh soal HSKK level dasar dengan kode soal H71003, H71311, serta HSKK level menengah dengan kode soal H81003, H81312. Satu set contoh soal HSKK level dasar terdiri atas 3 bagian yaitu: (1) Mengulang ujaran berbentuk kalimat, ada 15 soal, diselesaikan dalam waktu 6 menit, (2) Menyimak lalu menjawab pertanyaan, ada 10 soal, diselesaikan dalam waktu 4 menit, (3) Monolog/ menjawab pertanyaan sederhana, ada 2 soal, diselesaikan dalam waktu 3 menit.

Satu set contoh soal HSKK level menengah terdiri atas 3 bagian yaitu: (1) Mengulang ujaran berbentuk kalimat, ada 10 soal, diselesaikan dalam waktu 5 menit, (2) Berbicara berdasarkan gambar, ada 2 soal, diselesaikan dalam waktu 4 menit, (3) Monolog/ menjawab pertanyaan mengenai pendapat, perasaan mengenai sesuatu disertai alasan, ada 2 soal, diselesaikan dalam waktu 4 menit.

Berdasarkan pada acuan-acuan yang dipaparkan di atas, tim peneliti mendapatkan hasil sebagai berikut:

Tabel 10. Kesetaraan Materi Soal HSKK Level Dasar dengan CEFR

\begin{tabular}{|c|c|c|c|c|}
\hline \multirow[t]{2}{*}{ No } & \multirow[t]{2}{*}{ Materi Soal HSKK Level Dasar } & \multicolumn{3}{|c|}{$\begin{array}{l}\text { Kesetaraan } \\
\text { dengan CEFR }\end{array}$} \\
\hline & & $\mathbf{A 1}$ & A2 & B1 \\
\hline I. & Mengulang kalimat bertema kehidupan sehari-hari. (topik umum) & & & \\
\hline 1. & Transportasi yang digunakan untuk pergi. & $\sqrt{ }$ & & \\
\hline 2. & Ucapan selamat datang, terima kasih pada orang lain. & $\sqrt{ }$ & & \\
\hline 3. & Pujian terhadap orang lain. & & $\mathrm{V}$ & \\
\hline 4. & Benda milik diri dan orang lain. & $\sqrt{ }$ & & \\
\hline 5. & Informasi diri (usia, pekerjaaan, alamat, hobi, kegemaran). & $\sqrt{ }$ & & \\
\hline 6. & Keinginan dan rencana (mencakupi siapa, kapan, kegiatan). & & $\mathrm{V}$ & \\
\hline 7. & Kegiatan serta waktu terjadinya suatu kegiatan. & $\sqrt{ }$ & & \\
\hline 8. & $\begin{array}{l}\text { Memperkenalkan orang lain (nama, hubungan kekerabatan } \\
\text { dengan pembicara) }\end{array}$ & & $\sqrt{ }$ & \\
\hline 9. & Membandingkan sesuatu. & & $\mathrm{V}$ & \\
\hline 10. & Keadaan alam sekitar (cuaca). & & $\sqrt{ }$ & \\
\hline II. & Merespon ujaran bertema kehidupan sehari-hari (topik umum) & & & \\
\hline 1. & Waktu (hari, tanggal, tahun). & $\sqrt{ }$ & & \\
\hline 2. & Kemampuan (memasak, main basket) & & $\mathrm{V}$ & \\
\hline 3. & Kegemaran (makanan, menonton TV, warna, hewan peliharaan) & & $\mathrm{V}$ & \\
\hline 4. & Rencana. & & $\sqrt{ }$ & \\
\hline 5. & Menjelaskan mengenai teman baik. & & $\sqrt{ }$ & \\
\hline 6. & Menjelaskan mengenai keluarga (jumlah anggota keluarga) & $\sqrt{ }$ & & \\
\hline 7. & Tempat tinggal (tinggal dengan siapa). & & $\mathrm{V}$ & \\
\hline 8. & Cuaca. & & $\sqrt{ }$ & \\
\hline 9. & $\begin{array}{l}\text { Topik keseharian (belajar dimana, tidur jam berapa, hal yang } \\
\text { dilakukan saat senggang). }\end{array}$ & & $\sqrt{ }$ & \\
\hline 10. & Pengalaman (apakah pernah ke kota tertentu) & & $\sqrt{ }$ & \\
\hline III. & $\begin{array}{l}\text { Menggunakan frasa dan kalimat untuk berinteraksi dalam tema } \\
\text { kehidupan sehari-hari (topik umum) }\end{array}$ & & & \\
\hline
\end{tabular}


$1 . \quad$ Kegiatan sehari-hari (sebelum tidur malam).

2. Kegemaran, disertai alasan menggemari (berpergian, minum teh)

3. Mendeskripsikan orang lain (teman, sahabat, orang yang dicintai).

4. Mendeskripsikan tempat (sekolah).

Materi soal ujian HSKK level dasar berada pada rentang CEFR level A1 dan A2. Temuan ini sejalan dengan kenyataan bahwa HSKK level dasar mencakupi HSK level I hingga level 2. Meskipun materi ajar berupa gambar muncul di setiap tingkatan, sejak HSK level I hingga level IV. Namun pada HSKK level dasar tidak terdapat materi soal yang memerlukan deskripsi terhadap gambar. Materi soal demikian terdapat di HSKK level menengah.

Tabel 11. Kesetaraan Materi Soal HSKK Level Menengah dengan CEFR

\begin{tabular}{|c|c|c|c|c|}
\hline \multirow[t]{2}{*}{ No } & \multirow[t]{2}{*}{ Materi Soal HSKK Level Menengah } & \multicolumn{3}{|c|}{$\begin{array}{l}\text { Kesetaraan } \\
\text { dengan CEFR }\end{array}$} \\
\hline & & A1 & A2 & B1 \\
\hline I. & Mengulang kalimat & & & \\
\hline 1. & Transportasi yang digunakan untuk ke lokasi tujuan & & $\mathrm{V}$ & \\
\hline 2. & $\begin{array}{l}\text { Ucapan selamat ulang tahun dengan sopan (kepada orang yang } \\
\text { dihormati) }\end{array}$ & & $\mathrm{V}$ & \\
\hline 3. & $\begin{array}{l}\text { Pendapat seseorang mengenai sesuatu (buku, iklan di TV, } \\
\text { belajar) }\end{array}$ & & & $\mathrm{V}$ \\
\hline 4. & Menyampaikan berita & & & $\sqrt{ }$ \\
\hline 5. & Permintaan maaf dengan sopan & & $\mathrm{V}$ & \\
\hline 6. & Permintaan tolong dengan sopan & & $\sqrt{ }$ & \\
\hline 7. & Mendeskripsikan sifat orang lain & & & $\mathrm{V}$ \\
\hline 8. & Kegiatan yang dilakukan setiap hari (berolahraga) & & & $\sqrt{ }$ \\
\hline 9. & Rencana (mencakupi siapa, kapan, lokasi, kegiatan) & & & $\mathrm{V}$ \\
\hline 10. & $\begin{array}{l}\text { Waktu (sisa waktu dalam berkegiatan, keterlambatan dalam } \\
\text { berkegiatan) }\end{array}$ & & & 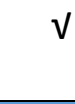 \\
\hline II. & Mendeskripsikan gambar & & & \\
\hline 1. & Kegiatan sehari-hari bertema bepergian & & & $\sqrt{ }$ \\
\hline 2. & Kegiatan sehari-hari bertema belajar & & & $\mathrm{V}$ \\
\hline III. & Menggunakan kalimat untuk berinteraksi & & & \\
\hline 1. & Pendapat mengenai orang lain, disertai alasan & & & $\mathrm{V}$ \\
\hline 2. & Pendapat mengenai perilaku tertentu, disertai alasan (diet) & & & $\mathrm{V}$ \\
\hline 3. & Membandingkan dengan diri yang sebelumnya & & $\mathrm{V}$ & \\
\hline 4. & Mendeskripsikan makna yang terkandung dalam pepatah Cina & & & $\sqrt{ }$ \\
\hline 5. & Pengandaian & & & $\mathrm{V}$ \\
\hline
\end{tabular}

Materi soal ujian HSKK level menengah berada pada rentang CEFR level A2 dan B1. Temuan ini sejalan dengan kenyataan bahwa HSKK level menengah mencakupi HSK level 3 hingga level 4.

\section{SIMPULAN}

Mengacu pada "Panduan Persiapan HSK" dan contoh soal ujian HSKK, peneliti berusaha menjawab pertanyaan penelitian yaitu mengenai kesetaraan antara HSK dengan CEFR pada keterampilan berbicara. Simpulan yang diperoleh peneliti yaitu sebagai berikut: 
1. Pada keterampilan berbicara, kesetaraan HSK, HSKK dengan CEFR dapat dilihat pada tabel di bawah:

Tabel 12. Kesetaraan HSK Keterampilan Berbicara, HSKK dengan CEFR

\begin{tabular}{|l|l|l|}
\hline \multicolumn{1}{|c|}{ HSK } & \multicolumn{1}{|c|}{ HSKK } & \multicolumn{1}{c|}{ CEFR } \\
\hline Level 1 & Level Dasar & 0 hingga A1 \\
\cline { 3 - 3 } Level II & & A2 \\
\hline Level III & Level Menengah & A2 hingga B1 \\
\cline { 1 - 1 } & & B1 \\
\hline Level IV & &
\end{tabular}

Berdasarkan tabel, materi ajar keterampilan berbicara HSK level I setara dengan CEFR 0 hingga level A1, HSK level II setara dengan CEFR level A2, HSK level III setara dengan CEFR level A2 hingga B1, sedangkan HSK level IV setara dengan CEFR level B1.

Materi soal HSKK level dasar setara dengan CEFR 0 hingga level A2, HSKK level menengah setara dengan CEFR level A2 hingga B1.

2. Materi ajar keterampilan berbicara HSK level I setara dengan CEFR level A1. Namun demikian, terdapat materi pada HSK level 1 yang belum mencapai CEFR A1. Materi yang dimaksud yaitu materi yang berkaitan dengan tata bunyi bahasa Mandarin.

3. Materi berupa gambar muncul di setiap tingkatan, sejak materi ajar HSK level I hingga level IV. Namun pada HSKK level dasar tidak terdapat materi soal yang memerlukan deskripsi terhadap gambar. Materi soal demikian terdapat di HSKK level menengah.

4. Simpulan peneliti sedikit banyak mempertimbangkan keterampilan menyimak, karena bagian menyimak menjadi bagian tak terpisahkan tes keterampilan berbicara.

Melalui penelitian ini telah didapatkan informasi mengenai kesetaraan HSK level I-IV dengan CEFR pada keterampilan berbicara. Pada pertemuan Forum Fakultas Bahasa dan Seni Indonesia di Universitas Negeri Gorontalo tahun 2019, telah disepakati bahwa penelitian kesetaraan HSK dengan CEFR sangat dibutuhkan, dan perlu dibuatnya versi dari pengajar bahasa Mandarin di Indonesia. Hasil penelitian dari Prodi Pendidikan Bahasa Mandarin UNJ akan diramu dan menjadi penelitian awal untuk landasan penelitian lanjutan yang akan dilakukan oleh prodi-prodi kependidikan bahasa Mandarin LPTK yang juga tergabung dalam Asosiasi Program Studi Mandarin Indonesia (APSMI).

\section{DAFTAR PUSTAKA}

[1] Deng Qiao, 2017. CEFR shijiao xia xi HSK 4 ji he IGCSE HSK Duibi Yanjiu. Thesis. Chongqing University.

[2] Emzir, 2010. Metodologi Penelitian Kualitatif Analisis Data. Jakarta: Rajawali Pers.

[3] Chen Changlai. 2005. Duiwai Hanyu Jiaoxue Gailun. Shanghai: Fudan Daxue Chubanshe.

[4] Council of Europe. Common European Framework of Reference for Languages: Learning, Teaching, Assessment. Cambridge Press.

[5] Common European frame work of reference for language: learning, teaching, assessment.

Diunduh 14 juli 2018, jam 19:29.

[6] Guojia Hanban. 2009. Guoji Hanyu Jiaoxue Tongyong Kecheng Dagang: Yinniyu, Hanyu

Duizhao. Beijing: Waiyu Jiaoxue Yu Yanjiu Chubanshe.

[7] Krippendorf, Klaus. Content Analysis An Introduction To Its Methodology. California: Sage Publications, 2004. 
[8] Pauw, Budianto dan Noviana Laurencia. 2014. "Keterkaitan New HSK dan Kurikulum Bahasa Mandarin di Perguruan Tinggi" dalam Jurnal Lingua Cultura. Vol.8 No.1.

[9] Richards, Jack C, 2001. Curriculum Development in Language Teaching. Cambridge: Cambridge University Press.

[10] Sah, Kedar P. 2012. "Assesment and Test in Teaching Learning" dalam Jurnal Academic Voices: A Multidisciplinary Journal. Vol. 2 No.1.

[11] Tarigan, Prof. Dr. Henry Guntur. 2013. Berbicara Sebagai Suatu Keterampilan Berbahasa. Bandung: Angkasa.

[12] Zhang Kai. 2006. Hanyu Shuiping Kaoshi (HSK) Yanjiu. Beijing: Shangwu Yinshuguan.

[13] Zhang Xiaotao. 2008. "Gaolunbiya Hanyu Kouyu Jiaoxue Diaocha yu Fenxi" dalam Jurnal Jinan Daxue Huawen Xueyuan Xuebao. Vol 4: 17-25

[14] Zhao, Jinming. 2006. Hanyu Keyi Zheyang Jiao: Yuyan Jineng Pian. Beijing: Shangwu Yinshuguan.

[15] http://www.hanban.org/tests/node 7486.htm diakses 21 Mei 2020 jam 10:30.

[16] https://en.wikipedia.org/wiki/Hanyu Shuiping Kaoshi\#cite note-hanban-8 diakses 21 Mei 2020 jam 10:40.

\section{DATA PENULIS}

\begin{tabular}{|c|c|}
\hline Nama & : Ayu Trihardini, M.A. \\
\hline Program studi & : S 1 Pendidikan Bahasa Mandarin \\
\hline Perguruan tinggi & : Universitas Negeri Jakarta \\
\hline Telp. & : 089636275155 \\
\hline Email & : ayu.trihardini@unj.ac.id \\
\hline Nama & : Aprilia Ruby Wikarti, M.A. \\
\hline Program studi & : S 1 Pendidikan Bahasa Mandarin \\
\hline Perguruan tinggi & : Universitas Negeri Jakarta \\
\hline Telp. & : 08979608797 \\
\hline Email & : apriliarubyw.s@unj.ac.id \\
\hline Nama & : Resma Nur Anggrini \\
\hline Program Studi & : Program Studi S1 Pendidikan Bahasa Mandarin \\
\hline Perguruan Tinggi & : Universitas Negeri Jakarta \\
\hline Telp. & : 082124102021 \\
\hline Email & : resmaanggrini@gmail.com \\
\hline Nama & : Riyadh Abdurrahman \\
\hline Program Studi & : Program Studi S1 Pendidikan Bahasa Mandarin \\
\hline Perguruan Tinggi & : Universitas Negeri Jakarta \\
\hline Telp. & : 085771661077 \\
\hline Email & : rydh1999@gmail.com \\
\hline
\end{tabular}

